\title{
GOOD GOVERNANCE DALAM TATA KELOLA PEREKONOMIAN MEMACU PADA PERTUMBUHAN EKONOMI RAKYAT
}

\author{
Tri Handayani \\ Universitas Wahid Hasyim Semarang \\ Email: tri.handayani1964@gmail.com
}

\begin{abstract}
Abstrak
Kemajuan suatu bangsa ditentukan oleh pengelolaan dalam sistem tata kelola pemerintahan yang baik. Good governance merupakan sebuah konsep dalam tata kelola pemerintahan yang mendasarkan pada pengelolaan negara yang bersih, amanah dan jujur. Manajemen pengelolaan dalam sistem tata kelola perekonomian merupakan hal terpenting guna memajukan konsep maupun program ekonomi kerakyatan. Konsep dasar yang perlu ditekankan adalah koperasi sebagai soku guru perekonomian rakyat, di mana sistem tata kelolanya mengacu pada pasal 33 UUD 1945. Penerapan good governance akan mendukung pemerataan dalam pelaksanaan pembangunan maupun pemerataan hasil-hasil pembangunan. Dengan demikian pertumbuhan dapat dinikmati oleh seluruh rakyat sehingga kesejahteraan rakyat yang menjadi tujuan pembangunan ekonomi nasional dapat terwujud.
\end{abstract}

Kata Kunci: good governance, pertumbuhan, ekonomi

\begin{abstract}
The progress of a nation is determined by the management in a good governance system. Good governance is a concept in goverment management based on the country management that are clean, trustworthy and honest. The management in economical system is the most important to advance the concept and the populist economic program. The basic concept that needs to be emphasized is cooperative as a stake holder for people, where the governance system refers to Article 33 of UUD 1945. The implementation of good governance will support the equalization in development or in the result of the development. Thus the growth of the development can be enjoyed by all people, so the welfare of the people will become the goal of economic development can be realized.
\end{abstract}

Keywords: good governance, growth, economic 


\section{Tri Handayani}

\section{A. Pendahuluan}

Kemajuan bangsa salah satunya dapat ditentukan melalui kembalinya sosok pemimpin negara yang jujur, berpadu dengan semangat kebangsaan yang siap berkorban kapan saja untuk nusa dan bangsa ini. Dapat dilihat cetusan keprihatinan Bung Hatta pada tahun 1958 bila digambarkan memiliki kondisi yang banyak persamaannya dengan kondisi ekonomi dan politik bangsa Indonesia pada waktu sekarang. Hal ini dapat dilihat dari adanya ketimpangan ekonomi di Indonesia yang masih begitu besar terutama di Jawa dan luar Jawa.

Etika kebijakan mengajarkan agar setiap kebijakan politik memberikan kebahagiaan bagi sebanyak mungkin warga masyarakat. Namun proses politik dalam formulasi kebijakan yang didasarkan dominasi elit penguasa dan terdepolitisasikannya masyarakat luas, menyebabkan kebijakan publik (public policy) pada masa Orde Baru berkecenderungan memberi peluang bagi elit penguasa dan golongan kuat lainnya, dan mengabaikan serta menyengsarakan golongan menengah ke bawah dan masyarakat lokal.

Kebijakan yang memprioritaskan pertumbuhan ekonomi yang cepat dalam pelaksanaan pembangunan perekonomian tanpa didampingi oleh kebijakan anti monopoli dan anti korupsi serta memandirikan lembaga peradilan, telah menyebabkan golongan menengah ke bawah dan masyarakat lokal terabaikan. Untuk mengejar pertumbuhan, pemerintah Orde Baru telah memberikan kesempatan kepada swasta untuk turut berperan serta dengan memberikan berbagai fasilitas dan proteksi, sehingga melahirkan konglomerasi yang menggurita ke segala bidang usaha. Penetesan ke bawah atau trickle down effect yang diharapkan ternyata tidak terwujud. Lebihlebih dengan munculnya sistem monopoli dan oligopoli dalam perekonomian yang hanya memberikan peluang pada pihak-pihak 


\section{Tri Handayani}

tertentu terutama yang dekat dengan elit penguasa dan adanya peluang korupsi, kolusi dan nepotisme, memunculkan kesenjangan atau gap yang semakin melebar antara golongan yang kuat dan golongan yang lemah dalam masyarakat.

Meskipun pembangunan pada waktu itu memperlihatkan kemajuan dalam berbagai bidang kehidupan, ternyata disertai dengan meluasnya kemiskinan, keterbelakangan, pengangguran dan kesenjangan sosial, dan mengindikasikan bahwa pembangunan memasuki perangkap "sukses yang merusak" atau dapat dikatakan sebagai keadaan sukses pertumbuhan yang tidak disertai distribusi manfaat yang merata. Hal tersebut justru menjadi bumerang bagi bangsa Indonesia.

\section{B. Pembahasan}

\section{a. Good Governance dalam Tata Kelola Perekonomian}

Saat ini terdapat kecenderungan semakin berkurangnya peran pemerintah di berbagai negara yang demokratis. Berkurangnya peran pemerintah ini bukan karena segala urusan diserahkan kepada mekanisme pasar, akan tetapi lebih disebabkan oleh tingkat partisipasi masyarakat yang semakin meningkat dan pilihan pengaturan kehidupan sosial, politik dan ekonomi yang lebih demokratis dan penciptaan good governance.

Kecenderungan tersebut di atas juga dikemukakan oleh Giddens dalam bukunya yang berjudul "The Third Way, The Renewal of Social Democracy". Menurut Giddens konsepsi negara kesejahteraan (welfare state) yang dianut oleh aliran demokrasi sosial klasik (the first way/jalan pertama) dan konsepsi fundamentalisme pasar (market fundamentalism) yang dianut aliran neoliberalisme (the second way/jalan kedua) kini sedang mengalami krisis. Oleh karena kedua konsepsi itu ternyata tidak mampu lagi menjawab persoalan-persoalan 


\section{Tri Handayani}

mendasar yang muncul sebagai akibat perubahan besar di tingkat global yaitu globalisasi ekonomi, pesoalan lingkungan, perubahan peran keluarga dan kerja, serta identitas personal dan budaya. Untuk itu Giddens menawarkan the third way (jalan ketiga) berupa konsepsi the radical centre, yaitu suatu model ekonomi pasar berskala global (globalized world) dalam masyarakat yang mengutamakan solidaritas sosial, yang antara lain ditandai prinsip persamaan, perlindungan yang lemah, kebebasan dalam bentuk otonomi, hak yang disertai tanggung jawab, otoritas yang dibentuk atas dasar partisipatoris, dan solidaritas dalam pluralisme.

Untuk mewujudkan gagasan-gagasan yang ada di dalam konsepsi the radical centre sebagai "jalan ketiga" itu, Giddens tetap memberikan tempat penting kepada masyarakat sambil merumuskan kembali peran negara yang tidak mungkin diabaikan begitu saja. Negara tidak lagi sendirian, melainkan harus didampingi sejumlah kelompok masyarakat dalam hal pengelolaan negara. Oleh karena itu, negara dalam pemikiran Giddens, harus mengalami pergeseran peran dari government menjadi governance, yaitu pengaturan sumber daya secara otoritatif dalam suatu komunitas dan negara. Dalam government negara merupakan instansi terpenting yang mengatur segala sesuatu dalam kehidupan bersama, sedangkan dalam governance, negara hanya berperan sebagai agen legulator dan agen administratif.

Governance diartikan sebagai mekanisme, praktek dan tata cara pemerintahan dan warga mengatur sumber daya serta memecahkan masalah-masalah publik. Dalam konsep governance, pemerintah hanya menjadi salah satu aktor dan tidak selalu menjadi aktor yang menentukan. Implikasi peran pemerintah sebagai pembangunan maupun penyedia jasa layanan dan infrastruktur akan bergeser 


\section{Tri Handayani}

menjadi bahan pendorong terciptanya lingkungan yang mampu memfasilitasi pihak lain di komunitas. Governance menuntut redefinisi peran negara, dan itu berarti adanya redefinisi pada peran warga. Adanya tuntutan yang lebih besar pada warga, antara lain untuk memonitor akuntabilitas pemerintahan itu sendiri. ${ }^{1}$

Pengertian negara harus dibedakan dengan pengertian pemerintah, karena keduanya memang berbeda. Larson sebagaimana dikutip Budiman² mengatakan, bahwa negara adalah sebuah konsep inklusif yang meliputi semua aspek pembuatan kebijakan dan pelaksanaan sanksi hukumnya, sementara pemerintah cuma sekedar agen yang melaksanakan kebijakan negara dalam sebuah masyarakat politik. Sementara Calvert menyatakan bahwa negara adalah "komunitas yang diorganisir untuk suatu tujuan politik", sedang pemerintah adalah "individu atau sebuah tim dari individu-individu yang mengambil keputusan yang memberi dampak bagi warga sebuah masyarakat".

Dari kedua pendapat tersebut Budiman menyimpulkan, bahwa negara bukan sekedar pemerintah. Negara merupakan sebuah fakta dominasi dari satu atau beberapa kelompok masyarakat untuk suatu tujuan tertentu. Aparat birokrasi (yang ada dalam pemerintah) hanya merupakan agen pelaksana dari negara. Yang dilaksanakan adalah kebijakan-kebijakan yang diputuskan oleh negara. Jadi negara pengertiannya bersifat abstrak, sedangkan birokrasi merupakan suatu yang konkret (nyata), sebab dia adalah lembaga eksekutif beserta orang-orang yang bekerja di dalamnya. Dia adalah pelaksana kekuasaan negara.

\footnotetext{
${ }^{1}$ Sumarto Hetifa Sj, Inovasi, Partisipasi dan Good Governance, (Bandung: Yayasan Obor Indonesia, 2003), hlm 1-2

2 Arief Budiman, Negara (Negara, Kekuasaan dan Teknologi), (Jakarta: PT. Gramedia Pustaka Utama, 1996), hlm 56
} 


\section{Tri Handayani}

Penjelasan mengenai perbedaan pengertian antara negara dan pemerintah sebagaimana dikemukakan di atas dianggap perlu, sebab peluang KKN hanya mungkin timbul dalam pemerintahan karena aparat-aparat birokrasinya bekerja di dalamnya sebagai pelaksana kekuasaan negara.

Good governance, yaitu pemerintahan yang dijalankan berdasarkan Pancasila dan UUD 1945 baik secara harfiah maupun menurut jiwanya, semangatnya atau sesuai dengan suasana kebatinan (geistlichen hintergrund)nya, yaitu pemerintahan yang mampu mewujudkan persamaan kedudukan antara sesama warga negara dihadapan hukum dan pemerintahan dan wajib menjunjung hukum dan pemerintahan itu dengan tidak ada kecualinya; pemerintahan demokratis yang mampu mewujudkan kehidupan demokratis di bidang politik, ekonomi, sosial, budaya dan agama, mewujudkan keadilan dan perikemanusiaan serta mampu memelihara budi pekerti kemanusiaan yang luhur dan memegang teguh cita-cita moral rakyat yang luhur. Jadi bukanlah suatu pemerintahan yang hanya mewujudkan kemakmuran ekonomi atau material saja, atau bagi golongan tertentu saja.

Penciptaan good governance bukan hanya melalui usaha membentuk pemerintah yang baik dan bersih saja, melainkan juga bagaimana membuat agar sistem dan tatanan yang ada dapat berjalan dengan sendirinya, atau secara ekstrim orang mengatakan governance without government. Dan tatanan yang demikian ini tidak mudah diciptakan. Untuk menciptakan tatanan tersebut diperlukan elemen pokok yang harus ada, yang menurut Soedarjono antara lain adalah adanya (1) transparansi dan keterbukaan, (2) partisipasi masyarakat, dan (3) sistem akuntabilitas (accountability) yang baik dan memadai. Kalau diamati, rezim Orde Baru telah gagal menjadi good governance. 


\section{Tri Handayani}

Lembaga perwakilannya kurang efektif, pengadilan tidak bersih, aparatur birokrasi korup, tak ada desentralisasi, dan masyarakat sipil tak berdaya. Akibatnya tidak ada transparansi, pertanggungjawaban maupun kontrol.

Perubahan peran negara di abad ini sebagaimana dikemukakan di atas menghendaki birokrasi modern yang efisien, bersifat kompetitif dan antisipatif, singkat, memberikan pelayan kepada masyarakat yag baik, tidak membuka peluang KKN, dan yang tidak lagi harus selalu memegang prinsip command and controle (arahan dan instruksi) tetapi lebih mengarah kepada recognize and respone (pengakuan dan respon).

Untuk menata ulang demokrasi Indonesia yang berbeli-belit, tidak efisien, tidak produktif, mutu pelayanannya rendah dan berpeluang KKN, barangkali konsep penataan ulang birokrasi atau pemerintahan yang ditawarkan oleh Osborne dapat dijadikan acuan. Tentu saja dalam implementasinya harus diadaptasikan dengan sosiokultural Indonesia dan diperlukan seorang pemimpin panutan yang terpercaya (trusted leader) agar berhasil dengan baik.

Osborne menawarkan "konsep pemerintahan wirausaha" (dengan memasukan semangat wirausaha dalam birokrasi, sehingga birokrasi harus dijalankan dengan logika-logika wirausaha) yang terdiri dari 10 prinsip, yaitu:

1. Perlunya pemerintahan yang katalistik yang lebih mengutamakan pemberian pengarahan daripada pemberian pelayanan (Catalytic Government: steering rather than rowing). Intinya bahwa jasa pelayanan publik sebaiknya diproduksi dan disediakan oleh sektor non publik, sementara pemerintah berfungsi untuk perumusan kebijaksanaan dan pengarahan saja. 


\section{Tri Handayani}

2. Perlunya pemerintahan yang dimiliki oleh masyarakat, yang mengutamakan pemberdayaan ketimbang pemberian pelayanan masyarakat (Community-owned Government: empowering rather than rowing). Intinya bahwa masyarakat harus diberdayakan sehingga dapat memecahkan masalahnya sendiri, dan mengurangi sebanyak mungkin ketergantungan masyarakat pada pemerintah.

3. Perlunya pemerintahan yang kompetitif, dengan menyuntikkan semangat persaingan dalam pemberian pelayanan (Competitive Government: injecting competition into service delivery). Intinya adalah monopoli pemberian pelayanan oleh pemerintah harus diakhiri, harus ada pemberi pelayanan lain non pemerintah (swasta). Dengan demikian pemerintah harus bersaing dengan swasta dalam pemberian pelayanan masyarakat. Melalui persaingan akan dapat ditingkatkan efisiensi, produktivitas, kreativitas, inovasi dan mutu pelayanan.

4. Perlunya pemerintahan yang didorong oleh misi (Mission driven government: transforming rule driven organization). Pemerintah dituntut untuk merumuskan misi secara jelas, kemudian memberikan kebebasan kepada seluruh aparat untuk menentukan cara-cara bagaimana masing-masing mencapai misi tersebut.

5. Perlunya pemerintahan yang berorientasi kepada hasil, yang mengutamakan penganggarannya untuk membiayai hasil, dan bukan masukan (input).

6. Perlunya pemerintahan yang berorientasi kepada pelanggan, yang berusaha memuaskan kebutuhan pelanggan dan bukan birokrasi (Customer driven government: meeting the needs of the customer, not the bureaucracy). Intinya adalah bahwa kepuasan masyarakat penerima jasa pelayanan pemerintah merupakan tujuan utama dari setiap kegiatan. 


\section{Tri Handayani}

7. Perlunya pemerintahan wirausaha yang menghasilkan ketimbang membelanjakan. Intinya bahwa pemerintah harus dapat menghasilkan pendapatan, bukan semata-mata menghabiskan anggaran.

8. Perlunya pemerintahan antisipatif yang mengutamakan pencegahan daripada pengobatan (Anticipatory government: preventing rather than cure). Intinya bahwa mencegah timbulnya masalah lebih diutamakan daripada penyelesaian masalah.

9. Perlunya pemerintahan desentralisasi, yang meninggalkan hirarki menuju partisipasi dan tim kerja. Kewenangan diberikan kepada aparat tingkat bawah yang melakukan pelayanan pada lini terdepan dengan masyarakat. Jenjang organisasi disederhanakan menuju struktur organisasi yang datar.

10. Perlunya pemerintahan yang berorientasi pasar, di mana berbagai perubahan didorong melalui pasar (Market oriented government: leveraging change through the market). Intervensi pemerintah dihindarkan, digantikan oleh kekuatan pasar dalam menjalankan berbagai fungsi pelayanan.

\section{b. Tata Sistem Perekonomian Indonesia}

Sistem Perekonomian adalah keseluruhan lembaga ekonomi baik yang tertulis maupun tidak tertulis yag dilaksanakan atau dipergunakan oleh suatu bangsa atau negara dalam mencapai cita-cita yang telah ditetapkan. Lembaga-lembaga ekonomi yang bersifat tertulis adalah Ketetapan MPR, UU, Kepres, RAPBN dan lain-lain. Sedangkan lembaga-lembaga ekonomi yang bersifat tidak tertulis adalah adat istiadat, kebiasaan dalam melaksanakan proses produksi, distribusi dan konsumsi, dan unit-unit kegiatan ekonomi lainnya. Lembaga-lembaga ekonomi itulah yang melakukakn fungsi-fungsi produksi, distribusi dan konsumsi terhadap barang dan/atau jasa. 
Landasan hukum sistem Perekonomian Indonesia adalah pasal 33 UUD 1945 yang dilatarbelakangi oleh jiwa UUD 1945 dan didukung oleh pasal 23, 27 (2), 34 serta penjelasan pasal-pasal tersebut. Sistem Ekonomi Pancasila dipertegas oleh rumusan yang dicantumkan dalam Garis-garis Besar Haluan Negara yang merupakan pedoman bagi kebijaksanaan pembangunan bidang ekonomi di Indonesia. GBHN merumuskannya sebagai berikut :

"Demokrasi Ekonomi menentukan bahwa masyarakat harus memegang peranan aktif dalam kegiatan pembangunan". Oleh karenanya maka pemerintah memberikan pengarahan dan bimbingan terhadap pertumbuhan ekonomi serta menciptakan iklim yang sehat bagi perkembangan dunia usaha, sebaliknya dunia usaha perlu memberikan tanggapan terhadap pengarahan dan bimbingan serta penciptaan iklim tersebut dengn kegiatan-kegiata yang nyata.

Demokrasi Ekonomi yang menjadi dasar pelaksanaan pembangunan memiliki ciri-ciri yang positif sebagai berikut:

1. Perekonomian disusun sebagai usaha bersama berdasar atas asas kekeluargaan.

2. Cabang-cabang produksi yang penting bagi negara dan menguasai hajat hidup orang banyak dikuasai oleh negara.

3. Bumi dan air dan kekayaan alam yang terkandung di dalamnya dikuasai oleh negara dan dipergunakan untuk sebesar-besarnya kemakmuran rakyat.

4. Sumber-sumber kekayaan alam dan keuangan negara digunakan dengan permufakatan Lembaga-lembaga Perwakilan Rakyat, serta pengawasan terhadap kebijaksanaannya ada pada Lembagalembaga Perwakilan Rakyat pula. 


\section{Tri Handayani}

5. Warga negara memiliki kebebasan dalam memilih pekerjaan yang dikehendaki serta mempunyai hak akan pekerjaan dan penghidupan yang layak.

6. Hak milik perorangan diakui dan pemanfaatannya tidak boleh bertentangan dengan kepentingan masyarakat.

7. Potensi, inisiatif dan daya kreasi setiap warga negara diperkembangkan sepenuhnya dalam batas-batas yang tidak merugikan kepentingan umum.

8. Fakir miskin dan anak-anak yang terlantar dipelihara oleh negara.

Pelaksanaan demokrasi ekonomi tentunya harus dihindarkan beberapa ciri-ciri negatif sebagai berikut:

1. Sistem free figth leberalism yang menumbuhkan eksploitasi terhadap manusia dan bangsa lain yang dalam sejarahnya di Indonesia telah menimbulkan dan mempertahankan kelemahan struktural posisi Indonesia dalam ekonomi dunia.

2. Sistem etatisme di mana negara beserta aparatur ekonomi negara bersifat dominan serta mendesak dan mematikan potensi dan daya kreasi unit-unit ekonomi di luar sektor negara.

3. Pemusatan kekuatan ekonomi pada satu kelompok dalam bentuk monopoli yang merugikan masyarakat.

Berdasarkan landasan tersebut di atas, Boediono mengatakan bahwa ciri-ciri perekonomian Pancasila adalah:

1. Peranan dominan dari koperasi, bersama dengan perusahaanperusahaan negara dan swasta. Kuncinya adalah bahwa "semua bentuk badan usaha didasarkan pada asas kekeluargaan dan prinsip harmoni dan bukan pada asas kepentingan pribadi dan prinsip konflik kepentingan".

2. Memandang manusia secara utuh bukan melalui "economicman" tetapi juga "social and religious man", dan sifat yang terakhir ini 


\section{Tri Handayani}

dapat dikembangkan setaraf dengan sifat yang pertama sebagai motor penggerak ekonomi.

3. Adanya "kehendak sosial yang kuat ke arah egalitarianisme atau kemerataan sosial".

4. "Diberikannya prioritas utama pada terciptanya perekonomian nasional yang tangguh". Konsep perekonomian nasional di sini ditafsirkan sebagai pemupukan ketahanan nasional, dan pemberian prioritas utama pada kepentingan nasional untuk mencapai suatu perekonomian yang mandiri, tangguh dan terhormat di arena internasional yang didasarkan atas solidaritas dan harmoni di dalam negeri.

5. Pengandalan pada sistem desentralisasi dalam pelaksanaan kegiatan-kegiatan ekonomi, diimbangi dengan perencanaan yang kuat sebagai pemberi arah bagi perkembangan ekonomi.

Pada tahun-tahun mendatang pemerintah Indonesia menghadapi dua macam tantangan dalam bidang perekonomian, yaitu tantangan dari dalam (internal) dan tantangan dari luar (eksternal). Tantangan internal berupa keharusan untuk membangun kembali perekonomian Indonesia yang hancur diterjang badai krisis moneter yang terjadi pada akhir era pemerintahan ORBA. Sedangkan tantangan eksternal berupa era globalisasi yang merupakan realita dalam memasuki milenium ketiga.

Agar bisa menjawab tantangan dan memanfaatkan peluang sehingga bisa keluar sebagai pemenang dalam era global, Indonesia harus segera berbenah dalam mempersiapkan diri. Karena hanya yang siap saja yang akan dapat bertahan dan terus maju. Leih-lebih di samping persaingan pasar, sekarang muncul interdependensi global yang baru, yaitu makin dominannya lembaga-lembaga internasional seperti IMF, World Bank dan WTO; serta meningkatnya regionalisasi 


\section{Tri Handayani}

atau pengelompokan pasar bersama di berbagai kawasan seperti MEE, NAFTA, AFTA, APEC.

Untuk bisa mengetahui kapan waktu yang tepat bagi Indonesia untuk mulai mempersiapkan diri menghadapi persaingan global, barangkali "analisis Large History" yang multidisipliner dari Kennedy bisa dijadikan acuan. Analisis tersebut dipergunakan oleh Kennedy untuk memperlihatkan perbedaan yang mendasar di antara perubahan-perubahan cepat yang melanda dunia pada abad ke 20 sekarang. Analisis mengikuti metode "Large History" dari perjalanan sejarah berbagai negara bangsa (Nation State) mendemonstrasikan adanya sekelompok negara bangsa yang muncul sebagai pemenang dan sekelompok lainnya tertinggal sebagai yang kalah, ketika proses perubahan yang fundamental dan bersifat revolusioner melanda dunia.

Analisis tersebut memperlihatkan, bahwa penyebab dari adanya winners dan losers tersebut adalah tidak samanya persepsi dan respon tiap negara bangsa terhadap perubahan revolusioner yang terjadi pada suatu kurun waktu tertentu. Ada sejumlah negara bangsa yang mampu dengan cepat menyesuaikan diri dengan perubahan (Fast Adjuster) dan melakukan reforms yang berani sebagai layaknya yang bersikap optimistis. Sedangkan sejumlah lainnya muncul sebagai slow adjuster, sebagai akibat respons yang didasarkan kepada cara pandang yang pesimistis, bahkan bersifat apocalyptic atau alarmists.

Kelompok yang terakhir tersebut memandang perubahan cepat yang terjadi sebagai ancaman; bahkan bahayanya, terhadap eksistensi negara bangsa, dan karena itu bersikap, perubahan itu harus ditentang dan bukannya disambut untuk dijadikan landasan bagi penyesuaian. Karena proses pengubah suatu keadaan pada skala besar memerlukan jangka waktu yang sangat lama untuk menimbulkan terobosan yang berbekas secara historis, maka menurut Kennedy, negara bangsa yang 


\section{Tri Handayani}

ingin melakukan adaptasi terhadap proses perubahan yang sedang terjadi harus memulai tindakan tersebut sejauh mungkin di muka. Dalam hal ini jelas bahwa yang diperlukan bukan hanya sikap yang tepat yang sesuai dengan jamannya, tetapi juga soal pemilihan waktu (timing) dimulainya proses adaptasi tersebut.

Berdasarkan yang dikemukakan di atas, maka pemerintah baru yang dibentuk sebagai hasil Pemilu 1999 harus segera mengambil sikap untuk mempersiapkan diri dan menyesuaikan diri dalam memasuki era global, agar bisa muncul sebagai pemenang (winners).

\section{c. Sistem Perekonomian Indonesia Masa Orde Baru}

Kecenderungan untuk menempatkan pembangunan ekonomi dalam kedudukan subordinasi kepada pembangunan politik pada masa ORLA telah membawa bangsa dan negara Indonesia ke tebing jurang kehancuran ekonomi. Angka inflasi pada tahun 1965-1966 mencapai $635 \%$ sedangkan pertumbuhan ekonomi nyaris stagnan.

Setelah terjadinya peralihan kekuasaan pemerintah ORBA mencanangkan pembangunan ekonomi sebagai prioritas utama. Untuk mendukungnya, pemerintah ORBA bertekad untuk memulihkan stabilitas politik nasional. Landasan kebijaksanaan pembangunan ekonomi tersebut adalah Ketetapan MPRS No.XXIII/MPRS/1966 tentang Pembaharuan Kebijaksanaan Landasan Ekonomi, Keuangan dan Pembangunan. Menurut pasal 10 TAP MPRS tersebut, pembangunan ekonomi harus didasarkan pada kemampuan dan kesanggupan rakyat Indonesia sendiri, disamping dapat pula memanfaatkan potensi-potensi modal, skill dan teknologi yang ada di luar negeri. Jelasnya sumber luar negeri hanya sebagai pelengkap dan sifatnya sementara.

Pelaksanaan pembangunan ekonomi tersebut berdasarkan pada Trilogi Pembangunan yang terdiri dari stabilitas, pertumbuhan dan 


\section{Tri Handayani}

pemerataan. Untuk meningkatkan pertumbuhan, pemerintah memberikan kesempatan kepada swasta nasional. Berbagai kebijaksanaan deregulasi dan debirokratisasi dikeluarkan oleh pemerintah untuk meningkatkan partisipasi swasta dalam pembangunan, sehingga swasta nasional tumbuh menjadi konglomerasi (yang merupakan diversifikasi usaha yang dapat dilakukan dengan cara pengambil-alihan, penggabungan dan konsolidasi). Meskipun kemudian terbukti hanya merupakan konglomerat semu (karena menjadi besar oleh subsidi dan proteksi pemerintah, serta utang yang berhasil diperoleh) dan keropos yang menjadi hancur ketika terjadi krisis moneter.

Struktur pasar monopoli dan oligopoli tersebut menyebabkan harga produk yang dihasilkan menjadi lebih tinggi (karena tidak ada barang subtitusi untuk barang yang dihasilkan dan perusahaan lain sulit untuk masuk ke dalam pasar atau industri), alokasi sumber kurang efisien dan terjadi kesenjangan dalam distribusi pendapatan. Akibatnya mekanisme pasar kurang berjalan, karena tidak ada persaingan yang sehat. Para konglomerat, monopolis dan oligopolis yang pada umumnya berskala besar, serta mempunyai kemampuan manajemen yang baik dan daya saing yang kuat, menghalangi perusahaan/industri kecil dan menengah masuk ke dalam pasar/industri, dan bahkan telah menyebabkan matinya industri kecil dan menengah.

Dalam bidang industri, strategi pembangunan yang dipilih sejak awal ORBA sampai sebelum tahun 1982 adalah industri substitusi impor. Dengan alasan bahwa industri substitusi impor relatif murah, pasar dalam negeri luas, menghemat devisa negara, melindungi infant industri dalam negeri yang sedang tumbuh dan menarik pengangguran (unemployment) dari pedesaan. Strategi industri substitusi impor 


\section{Tri Handayani}

dianggap kurang berhasil, karena ternyata bahan bakunya tetap didatangkan dari luar negeri dan lapangan kerja yang tercipta hanya sedikit karena yang dibangun adalah industri pasar modal. Di samping itu pemilihan strategi ini telah menempatkan negara dalam posisi hanya sebagai pasar sehingga selalu tergantung pada hutang luar negeri. Karena itu sejak tahun 182 diganti dengan strategi industri ekspor (export promotion) yang diharapkan bisa memberikan dampak positif berupa devisa negara serta dapat meningkatkan penghasilan eksportir dan produsen.

Kebijakan pemerintah yang memprioritaskan pertumbuhan selama hampir 30 tahun (1967-1997) telah berhasil menumbuhkan perekonomian Indonesia dengan rata-rata $7 \%$ per tahun. Namun demikian, trickle down effect (perembesan/tetesan ke bawah) yang diharapkan ternyata tidak menjadi kenyataan, karena tidak ada pemerataan hasil-hasil pembangunan. Kemiskinan, keterbelakangan, pengangguran dan kesenjangan sosial semakin luas.

Mengenai konflik antara pertumbuhan ekonomi dan pemerataan sebenarnya merupakan masalah klasik yaitu konflik antara orientasi makro dan mikro. Yang ideal adalah apabila pertumbuhan ekonomi yang tinggi diikuti oleh peningkatan pemerataan. Pertanyaannya adalah apakah pertumbuhan ekonomi tidak diperlukan? Untuk menjawab pertanyaan tersebut, Sumitro Djojohadikusumo mengemukakan, bahwa pertumbuhan dengan hasil produksi yang hanya dapat dinikmati oleh selapisan masyarakat yang terbatas, menimbulkan ketidakstabilan dan keresahan dan dengan sendirinya menggangu kestabilan dalam suasana kehidupan masyarakat. Sebaliknya, pemerataan tanpa peningkatan produksi membawa akibat kemiskinan yang meluas dan demikian akan pula menggangu kestabilan. 
Prioritas pada pertumbuhan ekonomi yang menimbulkan konglomerasi, monopoli dan oligopoli menunjukkan bahwa pemerintah melaksanakan sistem ekonomi kapitalis liberal (meski tidak dinyatakan secara terbuka). Ini bertentangan dengan "sistem ekonomi sebagai usaha bersama berasaskan kekeluargaan" atau Sistem Ekonomi Pancasila yang diamanatkan oleh pasal 33 UUD 1945, yang dijabarkan lebih lanjut dalam setiap GBHN. Dan oleh karena itu tujuan pembangunan nasional untuk mewujudkan keadilan sosial bagi seluruh rakyat di Indonesia tidak trcapai. Di samping itu, pada masa ORBA terjadi tumpang tindih antara politik dan ekonomi, di mana pelaku politik sekaligus juga bermain dalam bidang ekonomi. Hal ini mempunyai dampak pada munculnya korupsi, kolusi dan nepotisme (KKN) yang mengakibatkan ekonomi biaya tinggi (high cost economy).

\section{d. Kaitan Antara Good Governance dan Sistem Perekonomian yang Memacu Pertumbuhan dan Kesejahteraan Rakyat}

Tujuan pembangunan nasional adalah mewujudkan keadilan sosial bagi seluruh rakyat Indonesia. untuk mewujudkan tujuan tersebut harus dilakukan pemerataan "kue pembangunan". Dengan mengingat rakyat Indonesia yang jumlahnya sangat banyak tentunya diperlukan "kue pembangunan" yang besar. Sehingga strategi mengejar pertumbuhan ekonomi yang tinggi, tetap diperlukan.

Dalam melaksanakan strategi mengejar pertumbuhan ekonomi yang tinggi sesuai dengan prinsip pemerataan semua pelaku ekonomi (swasta nasional dari yang besar sampai yang kecil, koperasi dan BUMN) harus diberi kesempatan dan perlakuan yang sama. Sehingga pertumbuhan tidak hanya karena segelintir pengusaha, tetapi karena keikutsertaan semua pelaku ekonomi, atau pertumbuhan yang didukung oleh perekonomian rakyat semesta. Hal ini sesuai dengan politik ekonomi yang ditetapkan dalam Ketetapan MPR RI No. 


\section{Tri Handayani}

XVI/MPR/1998 tentang Politik Ekonomi dalam rangka Demokrasi Ekonomi.

Untuk dapat meningkatkan pertumbuhan yang didukung oleh pertumbuhan rakyat semesta diperlukan suatu pemerintahan yang bersih (good governance) di mana pelaku politik tidak ikut bermain dalam bidang ekonomi sehingga tidak ada peluang KKN (korupsi, kolusi dan nepotisme) karena hanya good governance yang dapat mendukung pemerataan dalam pelaksanaan pembangunan maupun pemerataan hasil-hasil pembangunan. Dengan demikian pertumbuhan dapat dinikmati oleh seluruh rakyat sehingga kesejahteraan rakyat yang menjadi tujuan pembangunan ekonomi nasional dapat terwujud. Dengan good governance maka birokrasi dapat menjadi penghubung antara kepentingan rakyat dan penguasa, sehingga kebijakan yang dirumuskan memiliki komitmen pemihakan nyata terhadap perekonomian rakyat. Bangsa ini tidak dapat membiarkan berlanjutnya birokrasi sebagai sebuah predator.

Dengan belajar dari pengalaman setelah terjadinya krisis ekonomi, maka buah pikir Bungaran Saragih yang menawarkan paradigma baru yaitu "sistem agrobisnis sebagai strategi pembangunan", dapat menjadi pertimbangan pemerintah untuk dipilih. Mengingat setelah terjadinya krisis ekonomi, yang masih dapat bertahan justru industri-industri berbasis pertanian.

Agrobisnis yang dimaksud bukan hanya pertanian, tetapi mencakup industri-industri yang menghasilkan sarana produksi bagi pertanian serta industri-industri pengolahan hasil pertanian (agroindustri) termasuk perdagangannya. Saragih yakin agrobisnis adalah alternatif terbaik untuk keluar dari situasi sulit Indonesia saat ini. Alasan pertama adalah karena agrobisnis kandungan bahan baku lokalnya tinggi. Sektor inilah dalam keadaan krisis sekarang yang 


\section{Tri Handayani}

masih bertahan bahkan menyumbang sektor netto. Keunggulan lain, agrobisnis menyerap banyak tenaga kerja dan dapat dikerjakan mulai dari pengusaha kecil, menegah sampai besar. Yang lebih penting lagi, agrobisnis adalah jembatan Indonesia menuju industri yang berbasis lebih luas, karena Indonesia sejak dulu dikenal sebagai negara agraris. ${ }^{3}$ Di samping itu, sektor pertambangan sektor pariwisata juga berpotensi sama dengan sektor agrobisnis.

\section{Simpulan}

Berdasarkan pembahasan di atas, dapat disimpulkan bahwa pilihan policy (kebijakan) dengan mengejar pertumbuhan merupakan pilihan yang tepat, akan tetapi ada distorsi, yaitu: tidak adanya keseimbangan pemerataan yang membawa kesejahteraan pada seluruh rakyat karena terlalu betumpu pada kepentingan elit bisnis tertentu yaitu kroni-kroni yang dekat dengan elit politik (kekuasaan); dan kegiatan bisnis yang semestinya terlepas dari kekuasaan sangat didominasi oleh kekuasaan, sehingga melahirkan KKN (korupsi, kolusi dan nepotisme), yang akibatnya hanya menguntungkan elit politik (kekuasaan) dan elit bisnis. Oleh karena itu sangat diharapkan adanya pemisahan antara elit politik (kekuasaan) dan elit bisnis, sehingga dapat menghapuskan KKN (korupsi, kolusi dan nepotisme). Hal tersebut dapat terjadi apabila ada distribusi dan alokasi bidang-bidang kekuasaan negara secara tegas dan jelas serta al ini dapat mendukung terwujudnya good governance.

\footnotetext{
3 Pambudy, Ninuk Mardiana. Reformasi ala Bungaran Saragih. Kompas. 24 November 1998. hlm 12.
} 


\section{DAFTAR PUSTAKA}

Abdul Aziz, Yaya M, Visi Global, Antisipasi Indonesia Memasuki Abad 21, Yogyakarta: Pustaka Pelajar, 1998.

Budiman, Arief, Negara (Negara, Kekuasaan dan Teknologi), Jakarta: PT Gramedia Pustaka Utama, 1996.

Hartono, Dimyati, 1997, Lima Langkah Membangun Pemerintahan yang Baik. Jakarta: Ind. Hill-Co, 1997.

Kennedy, Paul, Menyiapkan Diri Menghadapi Abad ke-21, Jakarta: Yayasan Obor Indonesia, 1995.

Mubyarto, Bung Hatta dan Perekonomian Rakyat (Dalam Pemikiran Pembangunan Bung Hatta), Jakarta: PT Pustaka LP3ES, 1995.

-------, Reformasi Sistem Ekonomi dari Kapitalisme Menuju Ekonomi Kerakyatan, Yogjakarta: Aditya Media, 1998

Ohmae, Kinichi, Dunia Tanpa Batas, Kekuatan dan Strategi di Dalam Ekonomi yang Saling Mengait (Alih Bahasa: FX. Budiyanto), Jakarta: Binarupa Aksara, 1991.

Osborne, Davud dan Ted Gaebler, Mewirausahakan Birokrasi, Reinventing Government. Jakarta: PT Pustaka Binaman Pressindo, 1999.

Simamarta, Dj. A, Reformasi Ekonomi Menurut Undang-Undang Dasar 1945. Jakarta: Lembaga Penerbit Fakultas Ekonomi Universitas Indonesia, 1998

Soroso, P.C, Perekonomian Indonesia, Jakarta: PT Gramedia Pustaka Utama, 1997

Soewito, Restrukturisasi Perusahaan (Makalah pada Seminar Nasional Pembanguan Hukum, Demokrasi dan Konstitusi di Indonesia 
Tri Handayani

Menjelang Abad XXII). Fakultas Hukum Universitas Diponegoro Semarang, 30 Juli 1990.

Kuliah-kuliah Sistem Ekonomi. Program Magister Ilmu Hukum Undip Semarang, 1999. 